УДК 625.1

\title{
ДИНАМІЧНІ ВИПРОБУВАННЯ ПОЛІМЕРКОМПОЗИЦЙНОГО ПРОКЛАДНОГО ШАРУ ДЛЯ ПЛИТ БЕЗБАЛАСТНОГО МОСТОВОГО ПОЛОТНА.
}

Канд. техн. наук С.В.Мірошніченко, інж. Н.М.Партала

\section{ДИНАМИЧЕСКИЕ ИСПЫТАНИЯ ПОЛИМЕРКОМПОЗИЦИОННОГО ПРОКЛАДНОГО СЛОЯ ДЛЯ ПЛИТ БЕЗБАЛЛАСТНОГО МОСТОВОГО ПОЛОТНА.}

Канд. техн. наук С.В.Мирошниченко, инж. Н.Н.Партала

\section{DYNAMIC TESTS POLIMERCOMPOSITION CUSHIONING LAYER FOR OF THE PLATES BALLASTLESS BRIDGE}

PhD Miroshnichenko Sergii V., eng. Partala Natalia N.

Наведено результати динамічних випробувань полімеркомпозиційного прокладного шару для плит безбаластного мостового полотна, як перспективної конструкиії 3 підвищеними характеристиками довговічності, як самої конструкиії так $i$ конструкиій рейкової колії.

Ключові слова: плити безбаластного мостового полотна,полімер композиційний прокладній шар,суха суміш,динамічні випробування

Приведены результаты динамических испытаний полимеркомпозиционного прокладного слоя для плит безбалластного мостового полотна, как перспективной конструкции с повышенными характеристиками долговечности, как самой конструкции, так и конструкций рельсового пути.

Ключевые слова: плиты безбалластного мостового полотна, полимер композиционный прокладной слой, сухая смесь, динамические испьтания

The results of dynamic tests polimerkompozytsiynoho cushioning layer for bridge plates undiluted canvas as prospective design with high durability characteristics of both the design and construction of rail tracks.

For testing it was determined polimerkompozytsiynoho compound that is able to withstand dynamic loads without appearances-of defects that are further able to reduce the durability of a cushioning layer structures and bridges and tracks.

Best performance epoxy composition was Sikadur-42 HE. Cushioning layer of this composition passed the full range of tests available without defects.

Polymer dry mixture SikaGrout-316 also withstood a full range of testing, but it had some cracks that do not affect the bearing capacity of the construction assembly.

Dry mix Emaco Fast Fluid small cracks in various directions and subsequent testing it is possible using compliant with metal mesh.

Keywords: boards bridge undiluted canvas, polymer composite cushioning layer, dry mix, dynamic tests

Вступ. Сполучення між верхнього поясу балки під кожною залізобетонними плитами безбаластного підрейковою основою плити. Як суцільний мостового полотна i головними або прокладний шар можугь використовуватися: поздовжніми балками металевих мостів армований цементно-піщаний розчин або виконується у вигляді суцільного дрібнозернистий бетон, безусадкова прокладного шару по всій довжині балок або швидкотвердіюча бетонна суміш наливного на дискретних опорах, які влаштовуються по 
Обрані праці 5-ї міжнародної науково-технічної конференції з будівельних матеріалів, конструкцій та споруд «Проблеми надійності та довговічності інженерних споруд і будівель на залізничному транспорті», Харків, 23-24 квітня 2015 року

типу з гумовою підкладкою, антисептовані дошки або фанера $з$ гумовими смугами і т.п.

Постановка проблеми у загальному вигляді та іï зв'язок із важливими науковими та практичними завданнями.

На залізницях України експлуатуються значна кількість металевих мостів 3 мостовим полотном на залізобетонних плитах БМП. Більшість 3 них укладені на дерев'яно-гумовому прокладному шарі. Це застаріле конструктивно-технологічне рішення призводить до передчасного виходу плит з ладу, необхідності заміни дерев'яних елементів кожні 7-10 років. Запропоноване раніше конструктивно-технологічне рішення полімеркомпозиційного прокладного шару забезпечує набагато більшу довговічність прокладного шару, плит БМП і мостового полотна в цілому. Проте технологія улаштування такого шару поки що залишається недосконалою, оскільки передбачає використання доволі складної комплексної опалубки, що ускладнює ऑï застосування та потребує збільшення тривалості «вікон».

Удосконалена технологія улаштування полімеркомпозиційного прокладного шару під збірним та збірно-монолітним залізобетонним безбаластним мостовим полотном збільшить довговічність конструкції верхньої будови колії та підвищить ii надійність, виключить необхідність у «вікнах» для виконання ремонтних робіп з заміни прокладного шару.

Аналіз останніх досліджень i публікацій. Виконаний аналіз сучасних конструкцій [1-3] дозволив зробити висновки о доцільності використання жорсткого прокладного шару, який дозволяє зменшити напруги у всіх елементах мостового полотна, i в зв'язку 3 цим подовжити їх довговічність.

Базуючись на використанні сучасних матеріалів [4] та комп'ютерне моделювання [5] зроблено висновок про можливість використання як полімеркомпозиційних матеріалів на базі епоксидної смоли, так і неорганічних матеріалів на базі цементів

Мета роботи - визначення полімер композиційного складу, який спроможний витримувати динамічні навантаження без виникнення дефектів, які в подальшому в змозі зменшити довговічність як прокладного шару, так i конструкцій мостової споруди і колії.

Розробка методики випробувань

Динамічні випробування здійснювали на масштабних моделях, за допомогою випробувальної машини МУП-50 (рис.1) 
Обрані праці 5-ї міжнародної науково-технічної конференції з будівельних матеріалів, конструкцій та споруд «Проблеми надійності та довговічності інженерних споруд і будівель на залізничному транспорті», Харків,

\section{3-24 квітня 2015 року}

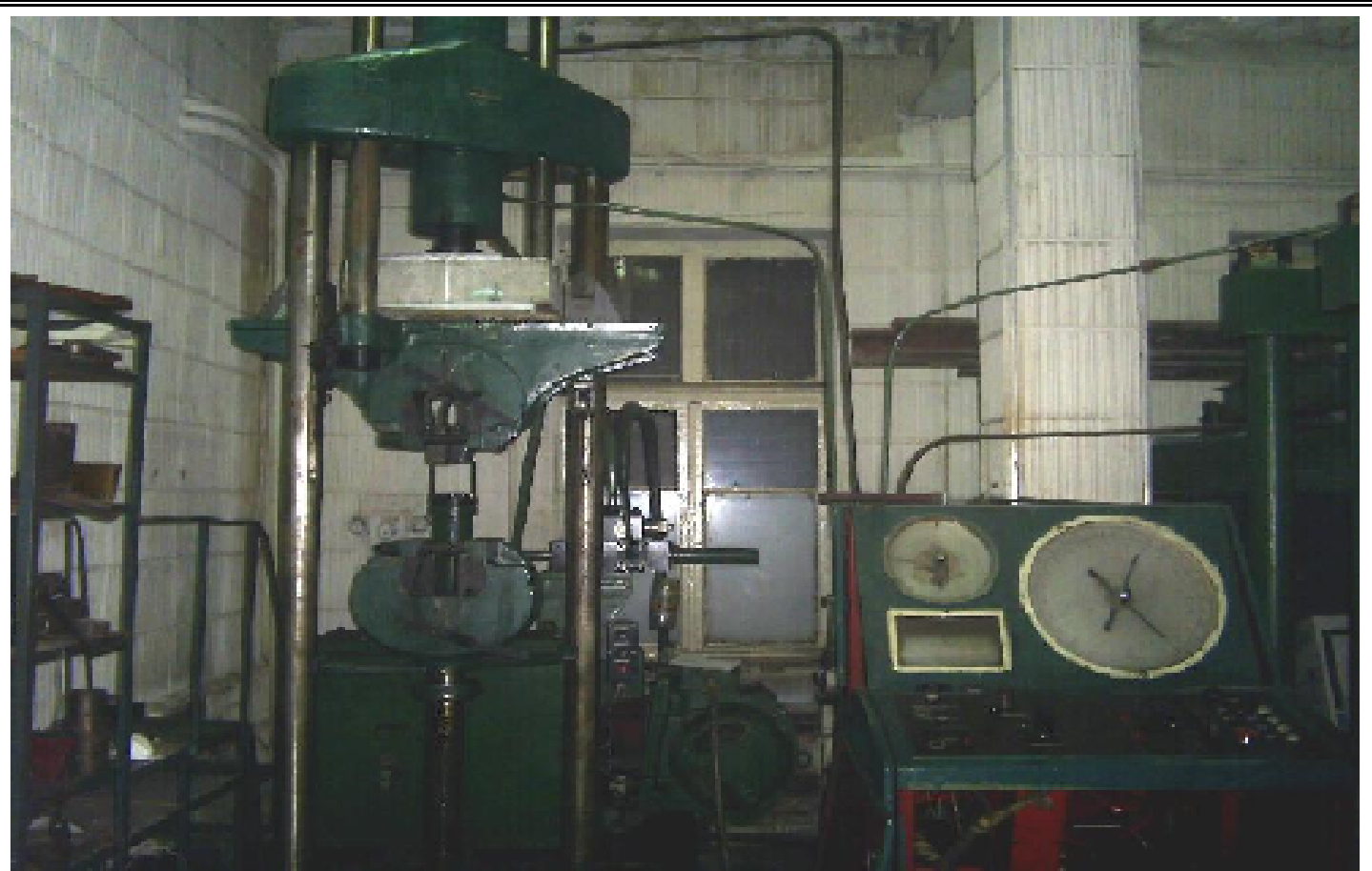

Рис. 1 Динамічні випробування масштабної моделі вузла сполучення верхньої полиці подовжньої балки моста, прокладного шару і плити БМП за допомогою випробувальної машини МУП-50

Діапазон динамічного навантаження призначали виходячи із таких міркувань. На експлуатованих мостах максимальне динамічне навантаження на одну підрейкову площадку складає 15 тс. Враховуюче те, що підрейкові площадки в існуючий плиті БМП розташовуються 3 шагом $50 \mathrm{~cm}$, а ширина прокладного шару повинна бути не менше 20 см, фактичне розподілене навантаження на прокладній шар складе 15 кгс/см².

Верхній поріг динамічного навантаження встановлено 15 тс, нижній поріг - 2 тс, частоту - 500 Гц, тривалість випробування - 2 млн. циклів. Випробування починали через 24 години твердіння прокладного шару і здійснювали по 6 годин на добу до досягнення 2 млн. циклів.

Вплив динамічного навантаження визначали за утворенням тріщин, відколів шляхом візуального огляду кожні 6 годин випробувань.

Для випробувань були використані: полімерцементна суха суміш Emaco Fast Fluid; полімерцементна суха суміш
SikaGrout-316;

епоксидна

композиція

Sikadur-42 HE.

Дослідження прокладного шару із полімерцементної сухої суміші Emaco Fast Fluid

Хід випробувань i розвиток пошкоджень:

- 106,5 тис. циклів - видалили джгути опалубки, пошкодження не спостерігаються;

- 376,5 тис. циклів - утворення у прокладному шарі 3 однієї сторони поперечної тріщини (рис. 2), яка розвивалась протягом наступних 200 тис. циклів;

- 576,5 тис. циклів - трішина розвинулась до наскрізної;

- 1241,5 тис. циклів - пошкодження прокладного шару у вигляді відколу ребра під звисом плити БМП і роздроблення у контактній зоні з металевою балкою (рис. $3)$;

- 1,5 млн. циклів - збільшення розкриття тріщини до 1 мм, утворення в прокладному шарі ще декількох трішин;

- 2 млн. циклів - випробування припинене, модель розібрана. 
Обрані праці 5-ї міжнародної науково-технічної конференції з будівельних матеріалів, конструкцій та споруд «Проблеми надійності та довговічності інженерних споруд і будівель на залізничному транспорті», Харків,

\section{3-24 квітня 2015 року}

Результати огляду (рис. $4-5)$ :

- зчеплення прокладного шару 3 металом балки слабке;

- 3 бетону плити прокладний шар знято в основному без зусиль, в окремих місцях за допомогою перфоратора;

- контакт прокладного шару 3 бетоном слабкий, зчеплення відсутнє крім місця заливного отвору, нерівності бетону матеріал прокладного шару не заповнив;
- контактна поверхня прокладного шару 3 боку плити БМП глянцева 3 ділянками затверділого цементного молока;

- у прокладному шарі спостерігались поперечні і поздовжні трішини;

- локальне руйнування (відколювання) прокладного шару під трішиною у залівобетонній плиті БМП (в місці концентратора напруги) - слід очікувати таке ж руйнування навколо високоміцних шпильок;

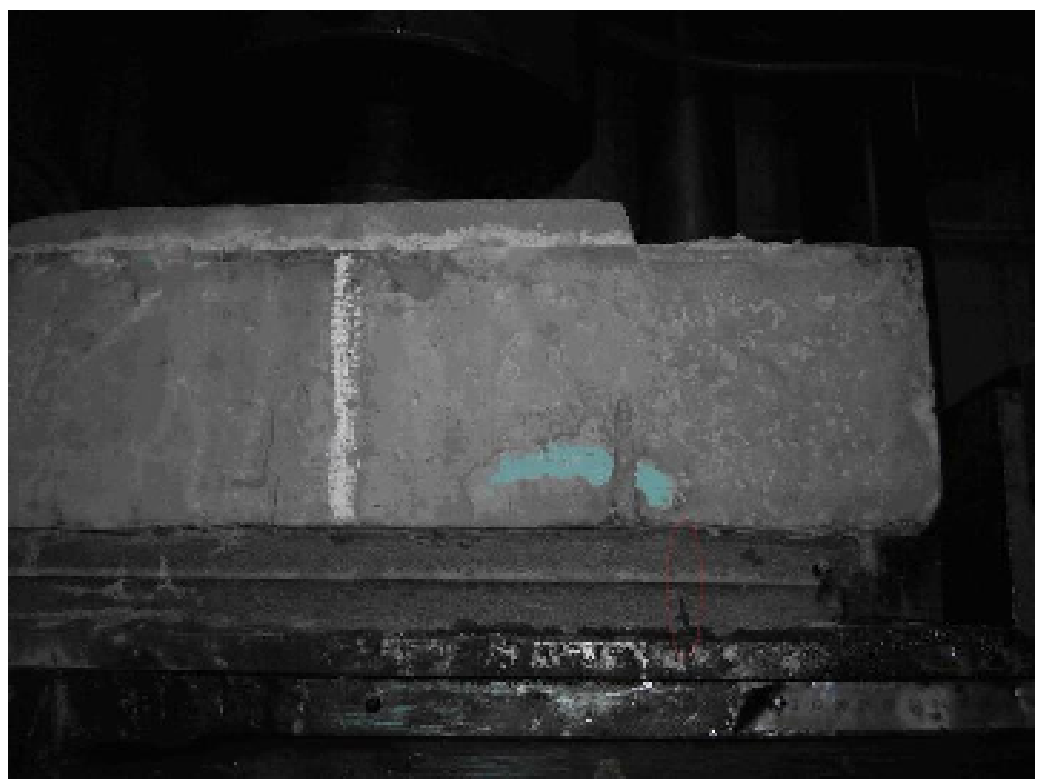

Рис. 2 Утворення у прокладному шарі з Emaco Fast Fluid поперечної трішини після 376,5 тис. циклів динамічних випробувань

Дослідження прокладного шару із полімерцементної сухої суміші SikaGrout316

Хід випробувань i розвиток пошкоджень:

- джгути опалубки видалені до початку випробувань;
- 380 тис. циклів - утворення у прокладному шарі 3 однієї сторони поперечної трішини;

- 2 млн. циклів - інших, крім вказаної трішини, пошкоджень не виявлено; випробування припинене, модель розібрана. 
Обрані праці 5-ї міжнародної науково-технічної конференції з будівельних матеріалів, конструкцій та споруд «Проблеми надійності та довговічності інженерних споруд і будівель на залізничному транспорті», Харків,

\section{3-24 квітня 2015 року}

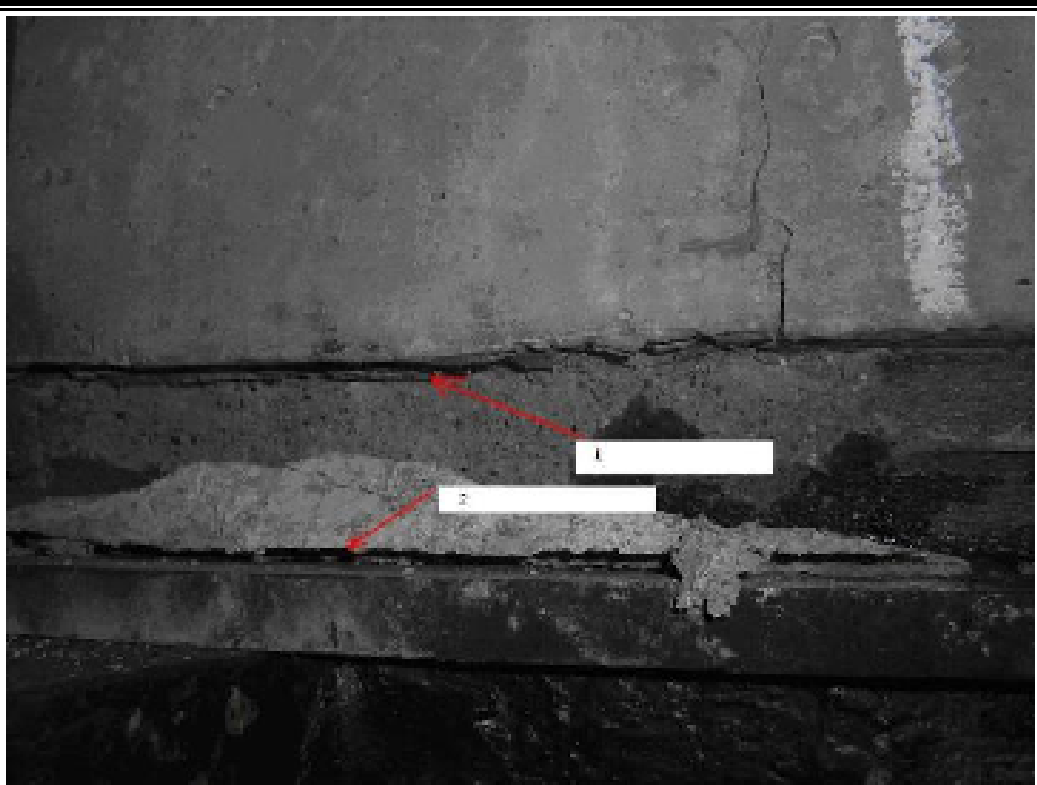

Рис. 3 Пошкодження прокладного шару з Emaco Fast Fluid після 1241,5 тис. циклів динамічних випробувань: 1 - відкол ребра прокладного шару під звисом плити БМП; 2 роздроблення прокладного шару у контактній зоні з металевою балкою

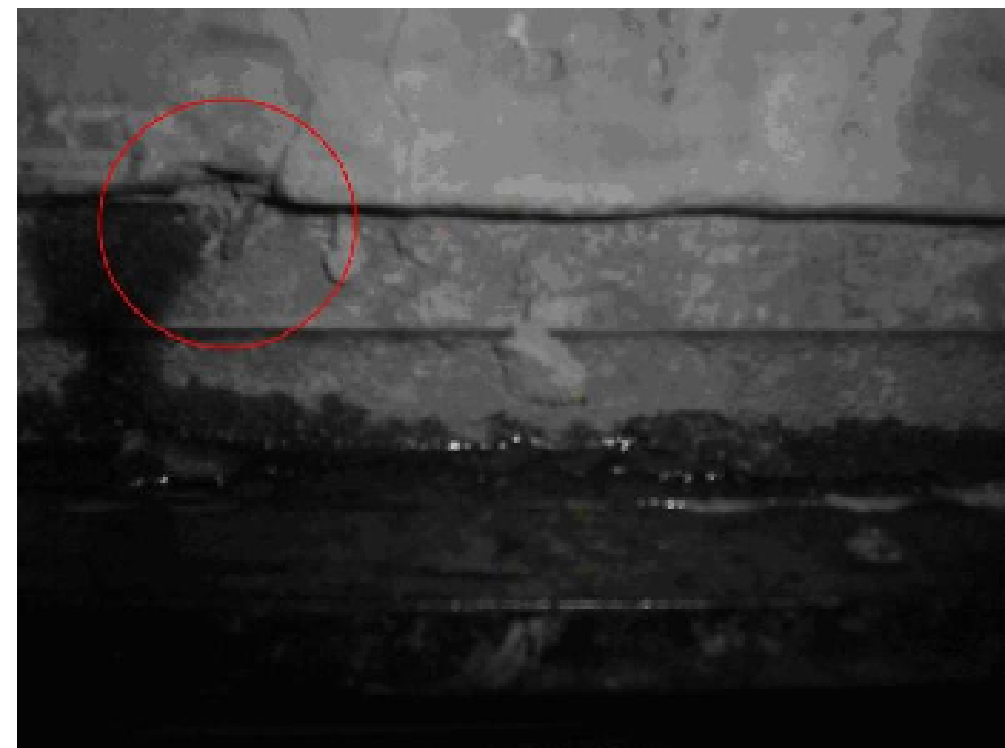

Рис. 4 Локальне руйнування прокладного шару з Emaco Fast Fluid в місці концентратора напруги - трішини в залізобетонній плиті БМП

Результати огляду (рис. $6-7)$ :

- зчеплення прокладного шару 3 металом балки збереглось, матеріал відділявся від металу лише за допомогою молотка;

- добре зчеплення прокладного шару 3 бетоном плити БМП, після видалення прокладного шару на бетоні відмічались його залишки; матеріал заповнив всі нерівності бетону і піднявся в отвір для витиснення повітря на 2-3 см;

- у прокладному шарі спостерігались 2 поперечні тріщини (рис.7) - одна наскрізна, за якою при розбиранні моделі прокладний шар розділився на окремі частини, друга не наскрізна. 
Обрані праці 5-ї міжнародної науково-технічної конференції з будівельних матеріалів, конструкцій та споруд «Проблеми надійності та довговічності інженерних споруд і будівель на залізничному транспорті», Харків,

\section{3-24 квітня 2015 року}

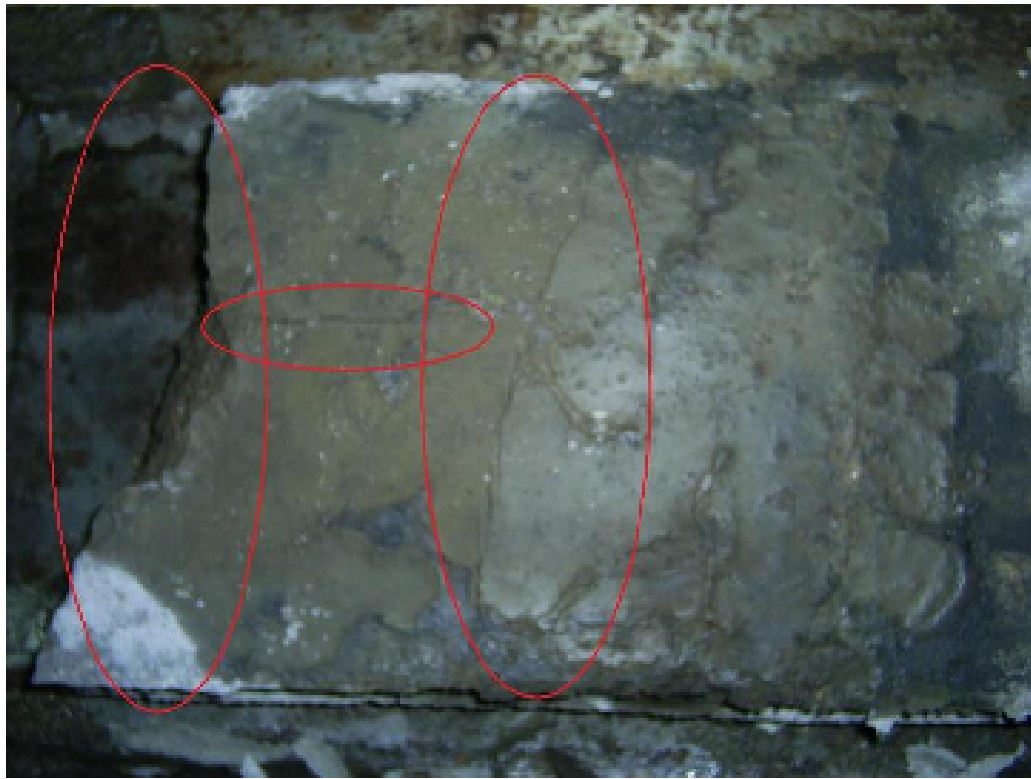

Рис. 5 Поздовжні і поперечні трішини у прокладному шарі з Emaco Fast Fluid після завершення динамічних випробувань

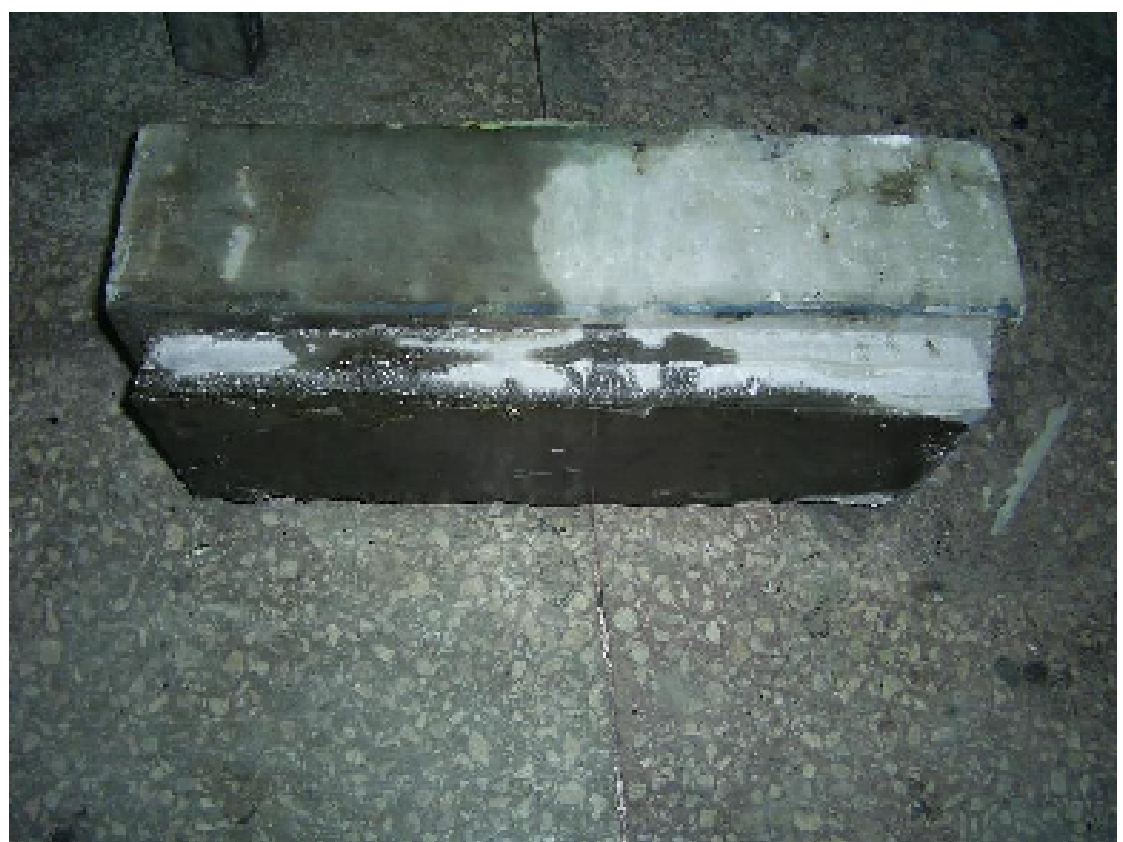

Рис. 6 Прокладний шар iз SikaGrout-316 після завершення динамічних випробувань i розбирання моделі: стан добрий, виявлено 2 поперечні тріщини з розкриттям не більше 0,3 мм 
Обрані праці 5-ї міжнародної науково-технічної конференції з будівельних матеріалів, конструкцій та споруд «Проблеми надійності та довговічності інженерних споруд і будівель на залізничному транспорті», Харків,

\section{3-24 квітня 2015 року}

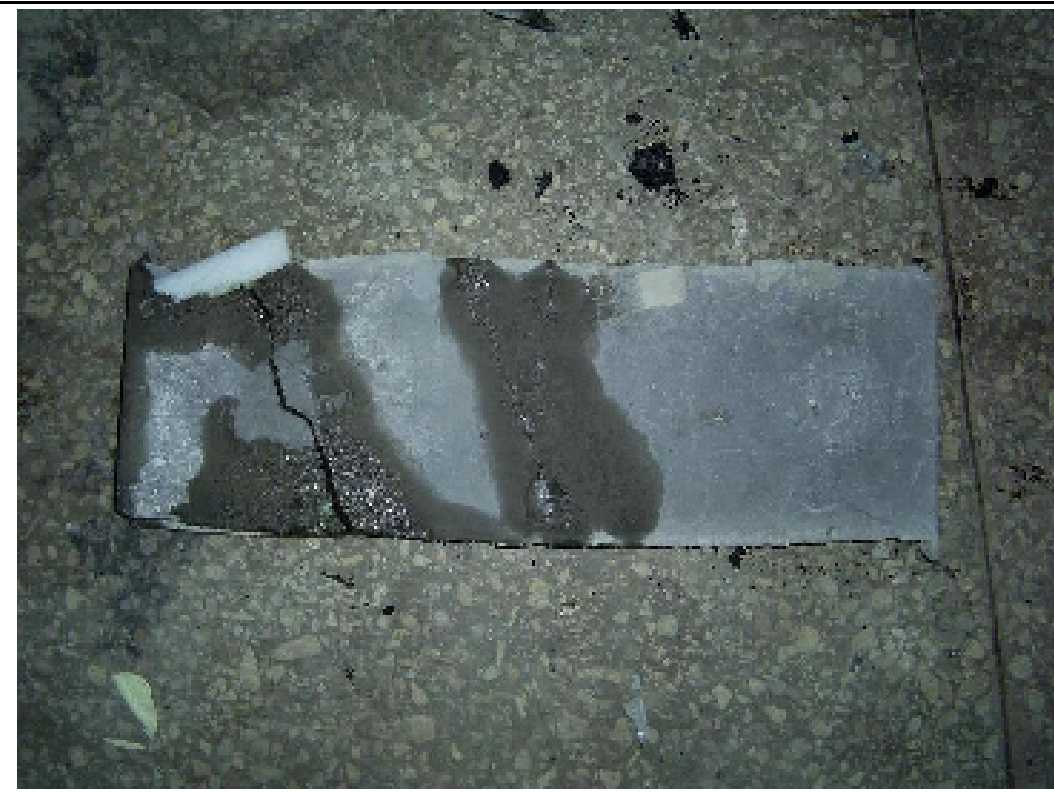

Рис. 7 Прокладний шар із SikaGrout-316 після завершення динамічних випробувань i розбирання моделі: поверхня, контактна з бетоном плити БМП - при розбиранні моделі прокладний шар по наскрізній трішині розділився на окремі частини, мастило просочило прокладний шар в районі волосяної тріщини.

Дослідження прокладного шару із епоксидної композиції Sikadur-42 HE

Паралельно 3 випробуваннями композиції Emaco Fast Fluid виконували випробування складу Sikadur-42 HE, однак в більш жорстких умовах (рис. 8). На поверхню балки було нанесено шар композиції товщиною 2 см. Навантаження передавалося через металеву круглу підкладку діаметром 15 см, тобто площа на яку передавалося навантаження склала 177 $\mathrm{cm}^{2}$, що в 5,6 разів менше ніж у складу 3 нижньої сторони моделі.

Випробування склад Sikadur-42 HE витримав без дефектів, та показав добрий запас міщності. Тріщин, розшарувань не відмічено (рис. 9).

\section{Висновки і рекомендації}

1. Найліпші показники мала епоксидна композиція Sikadur-42 HE. Прокладний шар 3 цієї композиції витримав повний комплекс випробувань без наявних дефектів.

2. Полімерцементна суха суміш SikaGrout-316 також витримала повний комплекс випробувань, але в ній виникли деякі тріщини, які не впливають на несучу здатність конструкції в зборі. Експлуатація такої суміші у якості прокладного шару допустима після експлуатаційної перевірки в польових умовах.

3. Суха суміш Emaco Fast Fluid мала тріщини в різних напрямах і подальше випробування iii можливо з використанням сумісно $з$ металевою сіткою. 


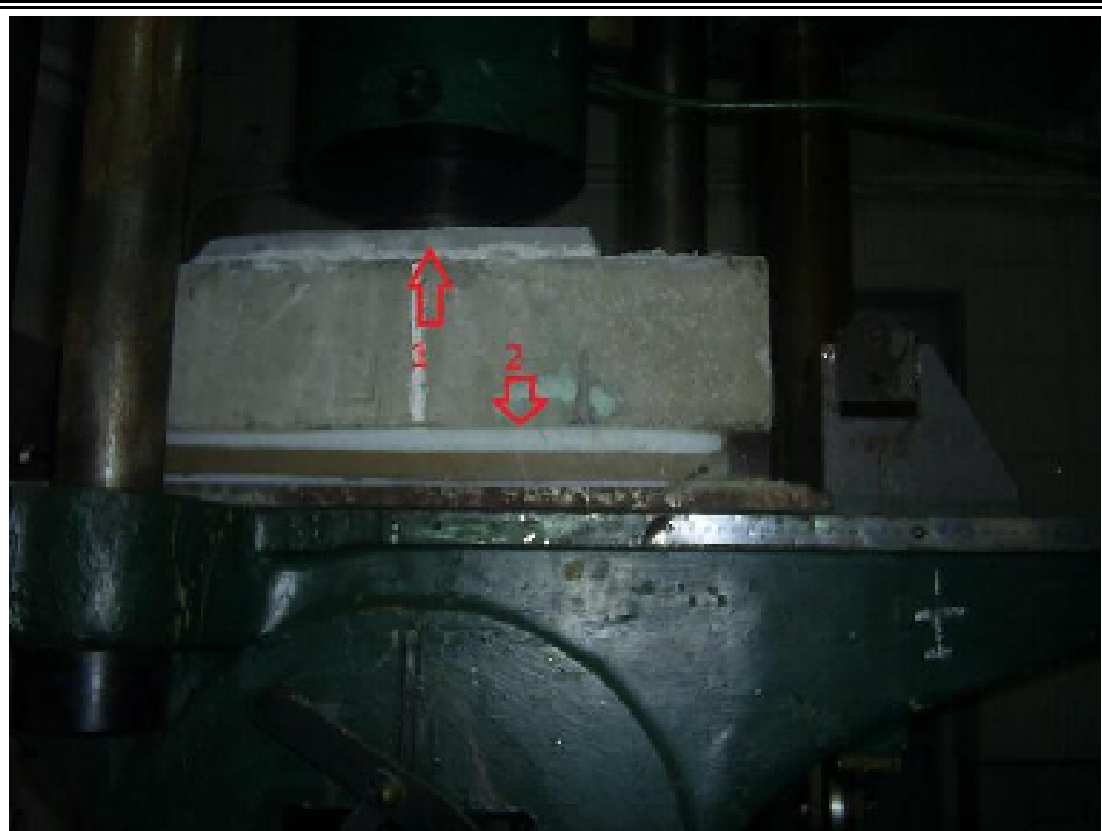

Рис. 8 Випробування складу із епоксидної композиції Sikadur-42 HЕ. (1 - склад Sikadur-42 HE; 2 - склад 3 нижньої сторони моделі).

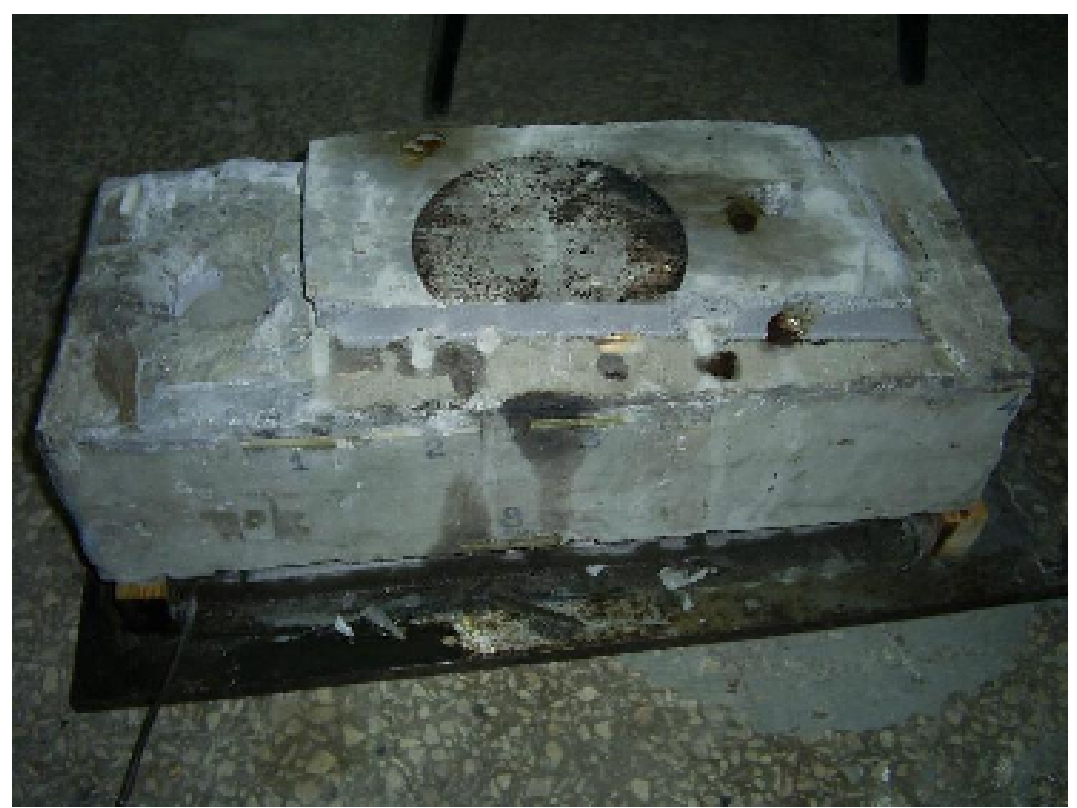

Рис. 9 Прокладний шар із епоксидної композиції Sikadur-42 HE після завершення динамічних випробувань і розбирання моделі

\section{Список використаних джерел}

1. Дослідження напруг і деформацій у плитах безбалластного мостового полотна / С.В. Мірошніченко // Зб.наук.праць УкрДАЗТ.- Харків: УкрДАЗТ, 2009.- Вип.109.- С.113-119

2. К вопросу исследования трещиностойкости железобетонных плит безбалластного мостового полотна / С.В.Мирошниченко, А.Н.Плугин, А.А.Плугин, И.Г.Корниенко // Будівельні конструкції: Міжвідомчий наук.-техн. збірник наук.праць.- К.: ДП НДІБК, 2009.Вип.72.- С.457-464.

3. К вопросу исследования трещиностойкости железобетонных плит безбалластного мостового полотна / С.В.Мирошниченко, А.Н.Плугин, А.А.Плугин, И.Г.Корниенко // Будівельні конструкції: Міжвідомчий наук.-техн. збірник наук.праць.- К.: ДП НДІБК, 2009.Вип.72.- С.457-464. 
4. Цементні та полімер цементні дрібнозернисті бетони для прокладного шару безбаластного мостового полотна із залізобетонних плит/ А.А.Плугин С.В.Мирошниченко, О.А.Калінін, Н.М.Партала, С.Г.Нестеренко, В.В.Перестюк// Зб.наук.праць УкрДАЗТ.Харків: УкрДАЗТ, 2014.- Вип.148.- С.39-45 (Index Copernicus).

5. Аналіз напруженно-деформованого стану плит безбаластного мостового полотна i прокладного шару під ними/ С.В.Мирошниченко, А.А.Плугин О.В.Лобяк, О.А.Забіяка, Г.О.Линник, Т.Шуба// Зб.наук.праць УкрДАЗТ.- Харків: УкрДАЗТ, 2014.- Вип.148.- С.104110 (Index Copernicus).

$$
\text { Рецензент д-р техн. наук Плугін Д.А. }
$$

Мірошніченко Сергій Валерійович к-т техн. наук, доцент кафедра будівельних матеріалів, конструкцій та споруд Український державний університет залізничного транспорту. Тел.: (057) 730-10-64 E-mail: smirosh70@yandex.ru

Партала Наталія Миколаївна завідувач лабораторії кафедра будівельних матеріалів, конструкиій та споруд Український державний університет залізничного транспорту. Тел.: (057) 730-10-63 E-mail: natabim@mail.ru

Miroshnichenko Sergii V., cand. of techn. sciences, docent, Head of Branch Research Laboratory of corrosion and corrosion protection of structures of railways, Ukrainian State University of Railway Transport.; Tel. (+38 057) 73010 64, E-mail: smirosh70@yandex.ru

Partala Natalia M..head of the Laboratory department building materials, structures and buildings Ukrainian State University of Railway Transport.; Tel. (+38057)7301063,E-mail:natabim@mail.ru

Стаття прийнята 25.05.2015 p 